\title{
From home to the film location site, from a film audience to a film tourist
}

\author{
XIN CUI, University of Liverpool
}

\begin{abstract}
A range of scholars in media studies suggest that film can enhance the awareness and appeal of the film locations because of its power of imagery (Macionis 2004; Beeton 2016; Riley and Van Doran 1992). Induced and motivated by film-related elements, audiences are no longer merely the recipients of film contents but also tourists who are going to visit the film-related sites. The journey of audiences visiting the film-related sites in person can be described as filmrelated tourism.
\end{abstract}

In this paper, the basic characteristics of film-related tourism will be introduced, demonstrating audiences' film journey to different types of film-related tourism sites, i.e., on-location film site and off-location film site (Beeton 2005). Then, it will use an off-location film tourism site Hengdian World Studios (HWS) in China as a case study to see audiences' travel experience as film tourists at the destination. To illustrate the touristic experience, this paper is going to apply the ethnography research method to show my personal film tour from home to the film sites in $H W S$, and thus examine the process of identity change from film audience to film tourist in the physical movement from home to the film location sites. Finally, authenticity issues, such as staged authenticity and existential authenticity, in film tours will be discussed in order to better understand audiences' on-site activities as well as the marketing strategies at the destination.

\section{KEYWORDS}

Film-related tourism, Hengdian World Studios, film tourist, travel motivation, authenticity

\section{Introduction}

The power of film on audience's behaviour as well as the resulting social change has long been discussed and debated among the scholars and experts, who work in the area of media and social science. Besides its influence on the development of a country's modern identity, image and cultural representations (Beeton 2016, 7), scholars contribute their work on the effects of film on audiences' behaviours from different perspectives, with some specifically focusing on the movement of film audiences from their local places, for example, home and local cinemas, to the film-related sites (Beeton 2016; Busby and Klug 2001; Macionis 2004; Connell 2012). A number of relevant definitions about this phenomenon have been introduced in previous 
studies, and some of them depict and define such phenomenon as film tourism/film-induced tourism/film-related tourism, i.e. people visit a destination as a result of it is being featured in a moving image, such as film, TV drama, DVD, digital media, video games, and film studio theme park 'reality' (Hudson and Ritchie 2006, 256; Connell 2012, 1009; Beeton 2015, 9).

Over the last three decades, there has been a growing interest in research in the field of film tourism (Oviedo-García et al. 2014, 714). People are witnessing the boost of film-related tourism and the popularity of some film sites around the world, for example, Harry Potter film tour and James Bond film tours in $\mathrm{UK}^{1}$, Hollywood film studio tours in US, The Lord of the Rings film tours in New Zealand, and Hengdian World Studios film tours in China. Therefore, it is worth realizing a long-standing fact that film audiences are no longer merely media-content recipients but they are also seeking out the places in person where they have previously seen in screen media, or involving film-related elements, in person. The journey from home to the film-related sites, on the one hand, can show their identity change to film tourists; on the other hand, it can indicate how people consider the authenticity issues in their film tour. In this regard, this article is going to demonstrate audiences' experience in Hengdian World Studios (HWS) in China to examine people's identity change and the authenticity issues in film-related tourism. It is able to contribute to the literature and research on audiences' touristic experience and activities in a film-related site, which may be utilized as the filming site, provide film-related activities and services, or represent film elements.

\section{Film-related tourism}

\section{Background Information}

Film-related tourism can be seen as a form of cultural tourism, which refers to people's movements with the purpose to satisfy their cultural needs to certain cultural attractions, including heritage sites, artistic and cultural manifestations, arts and drama outside their residential places (Richards 1996, 24; Jewell \& McKinnon 2008, 153). From this perspective, people's movement to film-related attractions and sites for satisfying their needs relevant to film art and culture could be generally understood as film-related tourism. In addition, the term 'film', in this case, includes film (movie), television, and the representations of other screen media (Yen \& Croy 2016, 1029). Hence, in film-related tourism studies, screen media in all its forms can have the potential to motivate and catalyse people's travel to the screen media sites. However, due to the complexity of people's understandings of the power of film and other screen media in motivating peoples' travel to film-related sites and the variety of people's filmrelated touristic experience, until now, the united name of this cultural tourism has not yet been agreed upon. We can see the names or terms to describe this in certain literature like 'film-

\footnotetext{
1 A range of travel agents in UK, such as Brit Move Tours and Visit London, organise the Harry Potter bus or walking film tours in Oxford and James Bond bus or walking film tour in London for tourists to visit the locations and relevant sites of Harry Potter films and James Bond films, such as the Great Dining Hall at Christ Church (featured in Harry Potter films) and Regent Street and Langham Hotel (featured in James Bond films).
} 
induced tourism' (Beeton 2005; Macionis, 2004), 'movie-induced tourism' (Riley, 1994), 'film tourism' (Hudson \& Ritchie 2006; Buchmann, et al 2010; Connell 2012, Yen \& Croy 2013), 'film-motivated tourism' (Karpovich 2010), 'screen tourism' (Connell \& Meyer 2009), 'filmrelated tourism' (Beeton 2011; Roberts 2016), and so on, though these phrases to some extent are used to depict and describe the common and general features of film-related tourism and could be interchangeably applied in most cases. In its most straightforward context, the broad definition of film-related tourism refers to the tourist activity induced by the viewing of moving images, including film, television, pre-recorded products, and digital media (Connell 2012, 1009), as well as video/computer games, film studio/theme park 'reality' experience, and holograms (Beeton 2015, 9).

In this article, considering the diversifications of screen media, film-related sites, and people's film tours, it will employ the term 'film-related tourism' to describe people's movements to the film-related sites. On the one hand, as Connell \& Meyer (2009, 194-195) expound, the term 'film' in film tourism serves to somewhat downplay the significance of TV dramas and shows in motivating tourism to the location sites, thus the term 'film-related' to some extent is trying to emphasize the importance of film in this cultural tourism as well as reduce the ambiguity of the inclusion of all screen media. On the other hand, in addition to filming sites or film location sites at the destination, for film tourists, other film-related elements, services, activities, events and facilities can also attract them to visit, for instance, film festivals, exhibitions, museums, workshops, theme parks, studios, souvenir stores, and so on. Beeton $(2005,180)$ suggests that the one-off film-themed events, such as film premieres and film festivals, can also generate tourism at the destination city. Therefore, the term 'film-related tourism' is also capable of comprehensively describing people's various types of film tour to the various types of filmrelated site.

\section{On-location film site and off-location film site}

Based on the features of different film-related attractions, Beeton (2005) systematically proposes two significant forms of film site - on-location film site and off-location film site. Generally, on-location film site refers to the existing buildings, built landscapes, and natural landscapes, for example, castles, hotels, main streets, and mountains (Beeton 2005, 210). Offlocation film site refers to the constructed set, studio site (separate from the naturally occurring setting of the moving image), and the representation of natural landscape, produced by computer imaging and other techniques, for instance, film studio sound stages, external facades constructed at a studio site, and vistas (Beeton 2005). In a word, on-location film-related tourism to a large extent refers to film tourists' journeys to the natural and existing locations, places, and landscapes represented in films, while off-location film-related tourism mainly refers to film tourists' journeys to the man-made and constructed film settings and sites, which are deliberately designed and built for film making and tourists' visitation.

In the category of on-location film-related tourism, Beeton $(2016,10)$ further characterizes several sub-categories of it, for example, 'film tourism pilgrimage' and 'nostalgic film tourism', 
which respectively characterize tourists" film tours as "visiting sites of film in order to "pay homage' to the film" and 'visiting film locations that represent another era'. Cases of film tourism pilgrimage sites and nostalgic film tourism sites are relatively common and widespread around all over the world, since some of the destinations mark these sites as the film-related locations to tourists by using indicators and plaques, such as the Hilary and Jackie film-site plaque in Brithdir Mawr, a Grade II-listed farmhouse near the small village of Cilcain in Flintshire (Roberts 2016,33), and some of these sites are frequently represented in films and other screen media, such as St George's Hall in Liverpool.

Liverpool is the UK's second most filmed city after London, and many of famous and popular sites have been used as the locations for hundreds of screen media works (Roberts 2016, 34). St George's Hall could be one of the most well-known architectures for media audiences and media works, like Fantastic Beasts and Where to Find Them (David Yates 2016), and Sherlock Holmes (ITV Granada 1984) even used it to stand in for the locations in other cities and in other eras, such as New York city in the 1920s and London city in the late Victorian era. Due to the popularity of these screen media works, St George's Hall also becomes a popular onlocation film tourism site, or more specifically, a film tourism pilgrimage site as well as a nostalgic film tourism site, for audiences who are willing to pay homage to these media works in Liverpool and who are interested in visiting the locations that represent different eras in these film-related works. To meet film tourists' needs to visit the film location, in 2019, Visit Liverpool also organized a 'St George's Hall - Film Tour' from April to May for people to better understand the connections between film and television works and this location. In their ticket-booking website of this film tour, Visit Liverpool (n.d) introduces:

"St George's Hall has created a fantastic new film and TV tour. The Hall is the original Liverpool film set, being the first place in Liverpool ever to be filmed, and as such has since played host to many memorable moments in film and TV. The film and TV tour offers the perfect opportunity to stand on the same film locations as some of the bestknown actors and presenters in the world. From Brookside to Fantastic Beasts and Where to Find Them, from Coca Cola, Coronation Street to Peaky Blinders, St George's Hall has provided the perfect backdrop for them all." (Visit Liverpool, n.d)

From this we can see that on the one hand, organising film tours and providing opportunities for people to be closer to their favourite celebrities in film and TV industries through standing at the same positions in St George's Hall to some extent indicate and reflect the local pride that the site has been featured in so many famous screen media works. On the other hand, this kind of film tour is also able to satisfy audiences' curiosity to the real heritage building, which may be a little bit different from the representations of it in media works. Moreover, in addition to using the heritage building as a filming site in films and television programmes, employing St George's Hall as the on-location film site for a short term reflects the popularity of film-related tourism in Liverpool.

In the category of off-location film-related tourism, based on the diverse features of film sites and touristic activities, Beeton $(2016,11)$ also divides off-location film sites into several forms, 
such as 'film studio tours', 'film studio theme park', 'museum', 'movie premieres', 'film festivals' and 'TV travel programmes'. Still, we can see many cases of off-location film tourism and off-location film sites around the world, such as film theme park tour in Disneyland (California, Orlando, Paris, Tokyo, Hong Kong, and Shanghai), film studio tour in Hollywood, and film studio theme park tour in Hengdian World Studios. In this article, I will focus on the case of film audiences' travel to Hengdian World Studios in China through using the ethnographic research approach to narrate my personal experience from home to the filmrelated sites, from a film audience to a film tourist, as well as to show my observation of other local tourists.

\section{Ethnographic research methods}

As Andrews, Jimura and Dixon $(2019,1)$ state, tourism study is a part of anthropology cannon as it is able to yield many insights about subjects at the heart of anthropological enquiry, such as the nature of the social world, questions of identity, host-guest relationships, and development and sociality. Hence, in researching on the study of tourism, the use of relevant anthropologic research methods is essential. Ethnography is the method closely associated with the academic discipline of social anthropology (Andrews, Jimura and Dixon 2019, 1). Focusing on fieldworks, ethnographic approaches connect the researchers with the people and objects at the fields. According to Andrews, Jimura and Dixon $(2019,3)$, the use of ethnographic research methods allow researchers to spend a certain period of time living among the people of the community under study, suggesting the idea that this will generate a deeper relationship with the local community members and a more in-depth understanding of their social life. To some degree, the core factors in conducting ethnography are 'being there' and 'doing there'. Hence, the use of ethnographic research methods, such as autoethnography and participant (tourist) observation, is therefore appropriate for understanding film audiences' touristic activities at the film-related sites.

Autoethnography can be considered as a critical method of inquiry (Noy 2007, 143), where the researchers' personal experience becomes part of the study itself. In tourism research, Beeton (2015, 30-31) expounds that autoethnography could be a powerful method because the researcher is immersed in the study and the more internal and personal reactions can be researched. In tourism research, researchers can also be a tourist to experience the tourism products and touristic activities in person, and apply the personal experience as the research data to manifest tourists' travel motivations, feelings, activities, emotions, and reflections as well as the characteristics of the destinations. Noy $(2007,143)$ suggests that 'autoethnography is a way of inquiry that is wholeheartedly - morally, emotionally and ideologically - committed to the subject of the research, namely to people and to their complex, intricate lives and experience'. In this respect, through conducting autoethnography, the research result is inevitably relatively subjective and privileges the researcher's personal emotions and experience. Even so, in addition to laying stress on the narrative of touristic experience on the locations, the autoethnographic approach can also be used to describe and depict the internal 
ideas of the researchers, such as memories, feelings, travel motivations, and retrospections. In film tourism research, such a method is compelling in addressing a tourist's whole touristic experience, especially the real changes of feelings, the peaks and troughs in his/her mood, and the psychological behaviours during the travel to the film sites. In fact, in the process of applying autoethnography, researchers examine themselves as the 'data' (Beeton 2016, xxi). Also, due to the specialty of its discursive written mode, the use of autoethnography can communicate and reconstruct the experience in vivid, lively and sometimes painful ways (Noy 2007), which may reinforce the interestingness or authenticity of the research results and cultivate a particular type of readership.

Besides, as Mitchell (2010, cited in Andrews, Jimura and Dixon 2019, 3) indicates, when ethnographers arrive at the 'fields', they may employ a variety of methods to collect data, participant observation being one of the best-known ethnographic methods. In addition to narrating researchers' journey stories by using autoethnography, the use of participant observation (tourist observation) can broaden the depiction and analysis of tourists' activities and behaviours through showing different people's activities and conversations in the locations. In this respect, I, as the ethnographer at the film-related sites, am both also the participant and the observer, since I am one of the members of the tourist community to experience the film tour and observe other members' film tours simultaneously at the destination. In other words, both my personal experience and my observation of other people's experience become the research data for comprehending film audiences' movement from home to the film-related sites and analysing their identity change to film tourists.

\section{Audiences' film touristic experience in Hengdian World Studios}

\section{Hengdian World Studios}

Located in the Hengdian town, Dongyang City, Zhejiang Province in China, Hengdian World Studios (HWS), is now the largest outdoor film studio in the world, with more than ten shooting bases and studios built for standing in for different styles of Chinese traditional buildings, architectures, and gardens and representing Chinese people's life in the past dynasties, such as Qin, Song, Ming and Qing Dynasties as well as the city of Hong Kong, Guangzhou, and Shanghai in the early modern era around the 1920s and 1930s [Figure 1-6]. Since the first film studio Guangzhou Street \& Hong Kong Street built in 1996 for making the film The Opium War (Jin Xie 1997), until now, more than 60,000 films and dramas were finished there, including a range of popular national and international film works, such as The Emperor and the Assassin (Kaige Chen 1998), Hero (Yimou Zhang 2001), The Mummy: Tomb of the Dragon Emperor (Rob Cohen 2008), and Detective Dee and the Mystery of the Phantom Flam (Hark Tsui 2010), as well as a large amount of television dramas such as Chinese Paladin (Taiwanese TV network 2005), Scarlet Heart (Hunan Television 2011), The Journey of Flower (Hunan Television 2015), and Ashes of Love (Jiangsu Television 2018). 

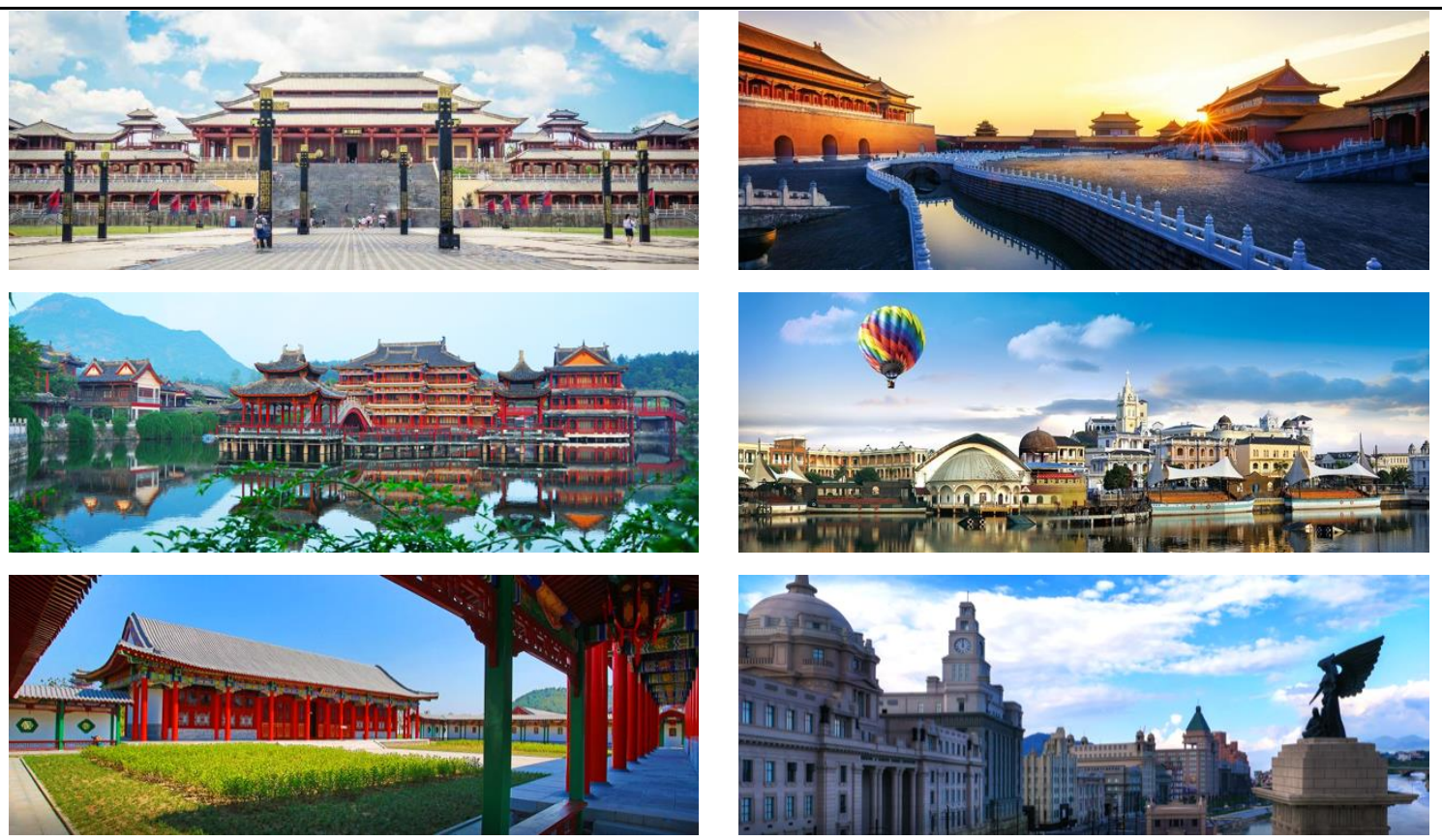

Figure 1-6: Film studios in Hengdian World Studios (Hengdian World Studios n.d)

It is also classified as the highest-level Tourist Attractions by China National Tourism Administration, and more than 2 million tourists visit Hengdian and HWS each year. In each studio, it has a specific theme to represent people's lives and landmarks in a specific period, and some of the studios are the simulations of the real heritage sites, for example, the film studio 'Palace of Ming \& Qing Dynasties' is an actual-size simulation (1:1) of the Forbidden City in Beijing. Studios like 'Palace of Emperor Qin' and 'Qing Ming Shang $\mathrm{He}$ Tu' are designed and built according to the official archaeological and historical resources and information for authentically reconstructing the buildings and environments and representing the life of civilians and royals in past Chinese dynasties. Due to the disappearance or the destruction of some real heritage sites in the wars or in some other incidents, the simulations in the studios also become unique physical objects for people to know the history in China, for example, 'New Yuan Ming Palace' in HWS is the to-scale simulation and reconstruction of the 'Old Summer Palace' in Beijing, which was destroyed in Second Opium War around the 1840s, only broken walls and debris left. Hence, functioning as an outdoor film studio and a film theme park, HWS is open to both media crews and tourists for filming works and visitation.

\section{Experience in Hengdian World Studios}

In May 2018, induced by some popular film-related works I previously have seen at home or in the cinema, and attracted by the local film-related elements in $H W S$, I left from home to take a film studio theme park tour in Hengdian for 3 days. During the film tour, I visited four film studios/shooting bases, including 'Palace of Ming \& Qing Dynasties' film studio, 'Palace of Emperor Qin' film studio, 'Qing Ming Shang He Tu' film studio, and 'Guangzhou Street \& Hong Kong Street' film studio, which respectively represent buildings, streets, and rooms in Ming \& Qing Dynasties (1368-1644, 1636-1912), Qin Dynasty (211-206 BC), Song Dynasty (960-1279), and early modern China (1910-1930s). The key reason I decide to visit them is 
that my favourite film-related works, such as Red Cliff (John Woo 2008), Painted Skin (Gordon Chan 2008), Empresses in the Palace (Anhui TV Station 2011), and The Legend of Mi Yue (Shanghai Dragon TV 2015), use the settings and backdrops in these studios for narrating their stories. In addition, another local attractive element is the special film-related touristic activity that tourists are allowed to observe the on-going work of film crews in $H W S$, even though the filming site will be fenced up in case of disturbances by tourists.

The on-site activities I, as a film tourist, did most in $H W S$ were site searching and image capturing. Induced by a series of film works, when I arrived at the film studios, I could not wait to seek out the places I have seen in some film-related works and figure out the 'authenticity' of the places. Through standing in the same places and doing the same poses with the film characters, the enjoyable memory of the film stories and characters' performance floods back in these locations. Also, for some film audiences, including me, when we arrived at the film locations, which are represented in our familiar and favourite film-related works, we will spontaneously and inevitably try to figure out if the real locations are as same as the fictional locations in the media works, and compare the differences between the real ones and the fictional ones. In the visitation to 'Palace of Emperor Qin' film studio, I noticed that one of the on-site tourists (audiences) excitedly said: "Look, this palace is the location in which Mi Yue (the female character in the television drama The Legend of Mi Yue) as the Queen Mother in Qin dynasty was standing to make the eve-of-battle speech for her soldiers! It is almost as same as the fictional location in this television drama, despite the lack of some special decoration".

I also had similar feelings when I found some popular film locations in 'Palace of Ming \& Qing Dynasty' film studio, where in film-related works plays as the Forbidden City's body double, which means a place stands in for another place through its selected parts, buildings and views (Paasonen 2015, 7), and I am aware that colours of the buildings actually are not bright and vivid as the filmic representations of them in media works, which may edit the screen images in the post-production stage. Even so, in addition to Couldry's $(2000,83)$ description "a sense of completion: 'to finally see everything'", in the film locations, I also generated another sense of completion: to finally experience everything, through seeing the buildings and following the characters' footsteps to visit the attractions in person. This kind of experience, for me, is finished by capturing the images of these locations. Roesch $(2009,159)$ expounds that taking images in the locations can be considered as the 'shot re-recreation', which means a person places himself/herself in the frame to re-create and represent the position of the film character. It seems that standing in the same locations, doing the same poses, and framing the location and me in one photo, is a continuous process to 'become' the character. Through observing and talking with other on-site film tourists/audiences, I found some of them also prefer to dress in the same costume as film characters and imitate their actions and facial expressions in the same place where the filmic event taken place. For them, dressing the same costume in the locations can make them be closer to the film stories and film characters since these audiences/tourists believe they are performing as a certain character of the media work. 
Furthermore, I fortunately got a chance to observe the on-going work of a film crew. It makes me feel excited to see how a film being made and how actors prepare their performance before acting. In my personal experience, the sense of self-fulfilment filled in my mind when I was close to the film-making sites, found the 'myth' of the film-making process, and understood the 'truth' and backstage of film performances. The sense of excitement can exactly show the evolution of audiences that we are no longer purely satisfied with the film contents represented on the media screens but we are also willing to know more about the behind-the-scenes stories and the backstage of film performance. In addition to the observation of film crews' work, some of the tourists in $H W S$ also signed up for playing as the short-term extra actors in the film works, possibly to understand more knowledge about film making.

In reality, people's movement from home to $H W S$ to some extent results in the identity change of them from film audiences to film tourists, and their on-site activities also change in relation to how they consider the authenticity issues in a film tour. In the next two sections, I will specifically discuss the features of people's identity change and their thoughts on the authenticity issues of film-related tourism.

\section{Identity change from film audiences to film tourists}

As Busby and Klug $(2001,316)$ indicate, when audiences are seeking the sites seen in films, they become film tourists. Namely, in the movement from home to film-related sites, audiences' identity is also changed to tourists, since they are not just 'watching' the sites on screens but they are going to 'see' and 'experience' the sites in the real locations. Hence, when discussing audiences' movement to the film-related sites, it is also worth considering the questions about the change of their identity to film tourists, for example, 'what motivates them to visit the filmrelated sites as film tourists?'. Such a question is actually relevant to the discussion of people's pre-trip motivations in film-related tourism.

For analysing people's pre-trip motivations, Dann (1977) suggests the 'pull' and 'push' motivational factor theory, and 'pull' factors and 'push' factors here respectively refer to the tangible features of a destination and the intangible and intrinsic desires of tourists. In other words, people can be motivated by the local natural environment, buildings, facilities, humans, services, activities and other tangible elements (pull factors) as well as the internal ideas, wishes, needs and other intangible desires (push factors) to visit a specific destination. Stemming from these, in film-related tourism, pull factors could therefore refer to all tangible film-related elements at the destination. Taking up Dann's theory (1977), Macionis $(2004,90)$ builds a ' $3 \mathrm{P}$ ' framework in the category of pull factor, suggesting the concepts of 'place', 'performance' and 'personality' in the investigation of the specific attributes of film-related tourism motivation. Place as a possible pull factor in this framework involves film location attributes, scenery, landscapes, cultural origin, social origin and activity origin. Performance relates to the filmic and fictional contents, such as storyline, plot, theme and genre, which draws people to the sites. Personality refers to human elements in a film, including film characters and the casts of them (Macionis 2004). Hence, for film audiences, some or all of 
these are able to motivate them to join in a film tour and move to the film-related sites. Moreover, in terms of push motivational factors in film-related tourism, based on some scholars previous' works (Dann 1977; Riley and Doren 1990; Macionis 2004; Meng and Tung 2016), they can be concluded as the issues about fantasy, escapism, search for self-identity, and partaking in a vicarious experience and educated tour, which are all related to the intangible desires of film audiences. As a result, it can be seen that the characteristics of local tangible elements at the destination work alongside audiences' personal intangible travel desires to motivate film tourists to visit the film-related sites.

In the case of film-related tourism in $H W S$, the local tangible film-related elements, such as the filming sites, film museum, film souvenir stores, film-themed live performance, film crews, actors/actresses, and props, can be understood as the pull factors, which play certain roles in motivating and stimulating film audiences' travel to Hengdian. With regards to the push factors, different people may have different travel desires, so the push factors could be various and comprehensive. For me, the push motivational factors can be seen as curiosity regarding the backstage of screen works and performances as well as the needs to partake in a vicarious experience of film characters in the environment full of film-related elements, and these factors also to a large extent result in my main on-site touristic activities, i.e., searching for the film locations, observing on-going works of film crews, and standing in the same places as film characters do in the media works and then taking photos. Similarly, for other audiences, their on-site activities are highly influenced by their push motivational factors. At the rest area in $H W S$, one on-site tourist told me that she is a superfan of the television drama Empresses in the Palace (Anhui TV Station 2011), which mainly uses the sites in 'Palace of Ming \& Qing Dynasties' film studio as its settings and backdrops, so she desires to seek out these location sites, take photos of them, and dress the same costumes of some female characters in this TV drama in order to have a deep connection with the dramatic story and the characters. From this we can see that in the same film-related sites, audiences could have different touristic activities. In other words, when audiences arrive in the film locations, their on-site activities more or less depend on their push motivational factors.

As Chhabra $(2010,798)$ suggests, previous research in tourism studies has established that tourists are not homogeneous. Indeed, people's different pre-trip motivations and on-site activities can lead them to become different types of tourist. It follows that in the movement from home to the film-related sites, audiences' identity is changing to different types of film tourists, considering their different motivations, demands, and consumption patterns (Cohen 1979; 1988; Pearce 1995, cited in Lovell \& Bull 2018, 5). Based on these, a range of scholars design and propose the film tourist typology for categorising different types of film tourists, for example, Macionis' film tourist typology (2004) of specific film tourist, general film tourist, and serendipitous film tourist. For Macionis $(2004,87)$, specific film tourist refers to the people who actively search for the places that they have seen in moving images; general film tourist refers to the people "who are not specifically drawn to a film location but who participate in film tourism activities while at a destination"; serendipitous film tourist refers to the people 
who are incidentally present in the film location site. Therefore, the term 'film tourist' can be regarded as a general concept to define audiences' identity in the film-related sites.

\section{Staged authenticity and existential authenticity in the film-related sites}

The debate about the authenticity issues in tourism research and studies has never stopped. One of the early discussions about it is Boorstin's arguments of the 'pseudo-event' (1964), which can be understood as a kind of ambiguous truth, and tourism is the prime example of the pseudo-event. For Boorstin (1964;1972), tourists in essence do not care if the touristic experience is authentic or not, and they travel to the destination, feel good in inauthentic contrived attractions, and place themselves in the 'environment bubble' (cited in Beeton 2016, 214; Urry \& Larsen 2011, 7-8). In contrast, MacCanell (1973, 597) insists that "touristic consciousness is motivated by its desire for authentic experiences [...]', namely, rather than overlook the authenticity, tourists are motivated by a quest for authenticity in their travel experience. In fact, the debate about whether tourists care about authenticity or not in tourism studies is long-standing but with no clear conclusion, perhaps because tourists are a heterogeneous group with various motivations and ideas about authenticity issues in their touristic experience. As tourism research continues, regarding authenticity in people's touristic experience and in tourism destinations, more and more scholars and experts further research on the different notions and concepts of authenticity in tourism, such as 'staged authenticity' (MacCannell 1973; Moscardo \& Pearce 1986; Lovell \& Bull 2018) and 'existential authenticity' (Berger 1973; Wang 1996; Brown 1996; Pons 2003; Lovell \& Bull 2018), which are also applicable to the research of film audiences' travel to the film-related sites (film-related tourism).

\section{Staged Authenticity}

In tourism research, MacCannell $(1973,597)$ suggests that touristic space can be called "a stage set, a tourist setting, or simply a set depending on how purposefully worked up for tourists the display is". From the perspective of a destination, the touristic site is regarded as a kind of commercial product, which is elaborately designed and laid out by the host for selling to tourists. Hence, in some ways what tourists see and experience in the touristic space is actually staged and, for MacCannell (1973), tourists who search for authenticity in their travel to a site can be the consumers of staged authenticity, which refers to the staging of local elements in order to create an impression of authenticity for the visitors (cited in Lovell \& Bull 2018, 5; Gotham 2010, 612). Based on Goffman's (1959) frontstage and backstage theory in performance, MacCannell $(1973,598)$ further points out the categorization of six stages in the discussion of staged authenticity (Form 1). For demonstrating the realm of social performance, Goffman (1959) generally divides the social area into two regions: front-stage region and backstage region, which respectively refer to the place where accentuated facts make an individual's appearance and the other place "where the suppressed facts make an appearance" (Goffman $1959,118)$. In a word, a front-stage region is the place for the visitors, while a back-stage region is the place only for the host. However, MacCannel (1973) suggests that the touristic space 
cannot simply be categorised into front-stage and back-stage regions but into several more specific stages. In some film-related tourism destinations, including Hengdian World Studios, some of the stages indeed exist with certain functions for certain purposes.

\begin{tabular}{|l|l|}
\hline Stage 1 & $\begin{array}{l}\text { Goffman's front region: the kind of social space tourists attempt to overcome, or } \\
\text { to get behind. }\end{array}$ \\
\hline Stage 2 & $\begin{array}{l}\text { A touristic front region that has been decorated to appear, in some of its } \\
\text { particulars, like a back region: a seafood restaurant with a fish net hanging on the } \\
\text { wall; a meat counter in a supermarket with three- dimensional plastic replicas of } \\
\text { cheeses and bolognas hanging against the wall. Functionally, this stage (two) is } \\
\text { entirely a front region, and it always has been, but it is cosmetically decorated } \\
\text { with reminders of back-region activities: mementos, not taken seriously, called } \\
\text { "atmosphere." }\end{array}$ \\
\hline Stage 3 & $\begin{array}{l}\text { A front region that is totally organized to look like a back region: simulations of } \\
\text { moon walks for television audiences; the live shows above sex shops in Berlin } \\
\text { where the customer can pay to watch interracial couples copulating according to } \\
\text { his own specific instructions. This is a problematical stage because the better the } \\
\text { simulation, the more difficult it is to distinguish it from stage 4. }\end{array}$ \\
\hline Stage 4 & $\begin{array}{l}\text { A back region that is open to outsiders: magazine exposés of the private doings } \\
\text { of famous personages; official revelations of the details of secret diplomatic } \\
\text { negotiations. It is the open characteristic that distinguishes these especially } \\
\text { touristic settings (stages } 3 \text { and 4) from other back regions; access to most non- } \\
\text { touristic back regions is somewhat restricted }\end{array}$ \\
\hline Stage 6 & $\begin{array}{l}\text { A back region that may be cleaned up or altered a bit because tourists are } \\
\text { permitted an occasional glimpse in: Erving Goffman's kitchen, factory, ship, and } \\
\text { orchestra rehearsal cases; news leaks } \\
\text { Goffman's back region: the kind of social space that motivates touristic }\end{array}$ \\
\hline consciousness.
\end{tabular}

Form 1: MacCannell's categorisation of six stages in staged authenticity (1973, 598)

Film studios like $H W S$, can be seen as a huge back region for film audiences/tourists, in which people can see the settings, backdrops, and the real locations of the film scenes or sequences as well as know more information behind the scenes. According to MacCannell's $(1973,598)$ categorization of six touristic stages, sites and attractions in Hengdian World Studios can be classified as the environment open to the tourists but which is actually considered a back-stage region (Stage 4), the environment with some limited access to tourists (Stage 5), and the absolute back region where all tourists are not allowed to enter (Stage 6). Specifically, film sites and attractions in $H W S$ which have been represented in screen media works for general audiences can be regarded as the back-stage region where audiences at home or in the cinema almost have no chance to see the full view of these places, while for film tourists, these places to some extent are the open areas, because they are legally allowed to enter in and visit the 
touristic sites in the studios. When audiences become film tourists in $H W S$, they may 'gullibly' believe they are visiting the back stages of the media works, however these places are actually the staged back regions, where the host intentionally operates for the commercial profits. In addition, there are still some other places, such as the on-going filming sites, in HWS where tourists have very limited access to visit and wander around. Through fencing up the filming sites, media crews clearly separate the spaces into front stage, where tourists can stand in and observe their on-going work, and the back-stage, where is the working places only for the crews. Also, inevitably, HWS needs the space for preparing their staged performance, and these places are the real back region, where only studio staff have the access to enter, such as film directors' working areas, prop rooms of film crews, and the restaurant kitchens in the studios.

As MacCannell $(1973,597)$ expounds, "it is always possible that what is taken to be entry into a back region is really entry into a front region that has been totally set up in advance for touristic visitation". Indeed, in the case of $H W S$, the back region of film works is designed as a kind of staged back region, functioning as the front region. What the studios represent and exhibit to audiences and tourists are set up as a regular touristic and theme park rides, however the real back regions in the studios are still invisible and inaccessible. In other words, for the audiences, who move from home to the film-related sites, the authenticity they can find in the destination is the staged authenticity that is well-designed by the studios. The authenticity here is 'invented' and manufactured represented as a commercial touristic product (Bruner 1991, 241; MacCannell 1973, 106, cited in Lovell \& Bull 2018, 5), provided for the audiences who look forward to seeing and experiencing the back region of screen media works and searching for the authenticity of sites related to these media works.

\section{Existential Authenticity}

In fact, not all tourists fail to realize that what they see in the destination could be a staged performance, but some of them may achieve an existential authentic experience through visiting the sites and doing the touristic activities. Rather than search for the objective authenticity, which highlights the sense of genuineness or realness of artifacts or events (Steiner \& Reisinger 2005, 299), some of the tourists are willing to seek out the existential authenticity in their travel, which refers to a state of being in which people are true to themselves (Berger 1973, cited in Steiner \& Reisinger 2005, 301). Namely, instead of looking for the authenticity of sites and attractions, tourists here are looking for the authenticity of themselves. Oriented by activities, in film-related tourism, existential authenticity is capable of helping film tourists to establish or extend their identity, and build the enjoyable connections with the film-related sites or the characters showed in screen media (Wang 1996; Rittichainuwat et al 2018). In the process of visiting the film-related sites and doing the film-related activities, audiences in the destination gradually reinforce their identity as film tourists and believe what they see and experience is authentic, even though some may be aware of the staged authenticity in the destination. In this regard, we can say audiences are the judges to determine whether their film tour is authentic or not, for example, in the case of $H W S$, existential authenticity indeed occurs 
in tourists' on-site experience when they find the sites they visit meet their pre-trip expectations, and they will thus believe their travel in the destination is existential authentic.

For the destination in film-related tourism, designing the film-related touristic activities and managing film-related site images could be able to catalyse the creation of film tourists' existential authenticity. In the case of HWS, the services and activities like film characters' costume rental services, the express photos of a film scene service, and extra actor services, can further help film audiences and tourists to be immersed in the on-site film-related environment and to feel enjoyment in the film-related sites, and thus have an existential authentic experience in their film tour. Catalysing tourists' existential authenticity can be also seen as a kind of marketing target in some film-related sites, which leads people to actively create a sense of authenticity rather than force them to be convinced of the so-called 'authenticity', intentionally designed by the host for commercial profit.

\section{Conclusion}

This paper discussed the movement of a specific group of audiences from their home to filmrelated sites. Undoubtedly, film has the power to attract audiences to visit the film sites and create a destination's tourist expectation, and the journey people go to the film-related sites, which are utilized as the filming sites, involve screen media elements, provide film-related services and activities, or represent film settings, can be understood as the film-related tourism. Through using an off-location film sites Hengdian World Studios as the example, this paper described film audiences' pre-trip motivations and on-site activities and feelings to see the reasons that people travel to the film-related sites and what they would do in the film-related sites. In the process of moving from home to film-related sites, people's identity is inevitably changed from audiences to tourists by doing a series of touristic activities. Also, in the discussion of staged authenticity and existential authenticity in film-related tourism research, $H W S$ can be seen as a case that the places film tourists see, visit and experience in the destination is the staged region and purposefully designed for tourist consumption. Nevertheless, audiences in the film-related sites do not passively accept the staged authenticity, purposefully set up by the host, but instead they can actively have an existential authentic experience, through achieving a state of being in which they are true to themselves.

The use of ethnographic research methods, including autoethnography and participant observation, in the case of $H W S$ is the foundation of this research project. Not only narrating the touristic experience in $H W S$, the use of ethnography can also demonstrate much more characteristics of film-related tourism in the destination, such as the impacts of film-related tourism on local residents' life. Moreover, due to the variety of ethnography, other relevant research methods, such as face-to-face interviews and questionnaires, can also be utilised to collect the data from different aspects and perspectives. Hence, in the further stages of the research on the film-related tourism in $H W S$, it is worthwhile to see the integration of multiple ethnographic research methods for enriching the research contents and results. 


\section{Filmography}

Films and TV Programmes:

Ashes of Love., 2018. [TV Programme] Jiangsu Television

Chinese Paladin., 2005. [TV Programme] Taiwanese TV network

Detective Dee and the Mystery of the Phantom Flam., 2010. [film] Directed by Hark Tsui. China: Huayi Brothers

Empresses in the Palace., 2011. [TV Programme]. Anhui TV Station

Fantastic Beasts and Where to Find Them., 2016. [film] Directed by D. Yates. US:

Warner Bros. Pictures.

Hero., 2002. [film] Directed by Yimou Zhang. China: Beijing New Picture Film.

Scarlet Heart., 2011. [TV Programme] Hunan Television

Sherlock Holmes., 1984. [TV programme] ITV Granada

The Emperor and the Assassin., 1998. [film] Directed by Kaige Chen. US: Sony Pictures Classics

The Journey of Flower., 2015. [TV Programme] Hunan Television

The Mummy: Tomb of the Dragon Emperor., 2008. [film] US: Universal Pictures.

The Opium War., 1997. [film] Directed by J. Xie. Hong Kong China: Golden Harvest. 


\section{References}

Andrews, H., Jimura, T. \& Dixon, L., 2019. Tourism Ethnographies: Ethics, Methods, Application and Reflexivity. Oxon: Routledge.

Beeton, S., 2005. Film-induced Tourism. Bristol: Channel View Publications.

Beeton, S., 2011. Tourism and the Moving Image - Incidental Tourism Promotion. Tourism Recreation Research, 36 (1), pp. 49-56.

Beeton, S., 2016. Film-induced Tourism. Bristol: Channel View Publications.

Berger, P., 1973. Sincerity and Authenticity in Modern Society. Public Interest. (31), pp. 81-90.

Boorstin, D. J., 1961. The Image: A Guide to Pseudo-Events in America. New York: Harper \& Row.

Boorstin, D.J., 1972. The Image: A Guide to Pseudo Events in America. New York: Atheneum.

Brown, D., 1996. Genuine Fakes. The Tourist Image: Myths and Myth Making Tourism. T. Selwyn (ed). pp. 33-47.

Buchmann, A., Moore, K., \& Fisher, D., 2010. Experiencing film tourism: Authenticity \& fellowship. Annals of Tourism Research. 37(1), pp. 229-248.

Busby, G. \& Klug, J., 2001. Movie-induced Tourism: the Challenge of Measurement and Other Issues. Journal of Vacation Marketing, 7(3), 216-232.

Chhabra. D., 2010. Back To The Past: A Sub-Segment of Generation Y's Perceptions of Authenticity. Journal of Travel Research. 44, pp. 64-73

Cohen, E., 1979. Rethinking the Sociology of Tourism. Annals of Tourism Research. 6(1), pp. 18-35

Cohen, E., 1988. Authenticity and Commoditization in Tourism. Annals of Tourism Research. 15, pp. 29-46.

Connell, J. \& Meyer, D., 2009. Balamory Revisited: An Evaluation of the Screen Tourism Destination - Tourist Nexus. Tourism Management. 30, pp. 194-207.

Connell, J., 2012. Film Tourism - Evolution, Progress and Prospects. Tourism Management, 33, 1007-1029.

Couldry, N., 2000. The Place of Media Power: Pilgrims and Witness of the Media Age. London: Routledge.

Dann, G. M. S., 1977. Anomie, Ego- Enhancement in Tourism. Annals of Tourism 
Research. 4(4), pp.184-194.

Goffman, E., 1959. The Presentation of Self in Everyday Life. London: Penguin Gotham, K. F., (2010). Tourism and Culture. Handbook of Cultural Sociology. John R. Hall, Laura Grindstaff,. \& Ming-cheng Lo (ed). pp. 608-616.

Hengdian World Studios, n.d. Tourist Attractions. [online]. Hengdian World Studios. [Viewed on 15 th March 2020]. Available from: http://www.hengdianworld.com/Scenic_QWG/

Hudson, S., \& Ritchie, R., J. , 2006. Film Tourism and Destination Marketing: The Case of Captain Corelli's Mandolin. Journal of Vacation Marketing, 12(3), 256-268.

Jewell, B., \& McKinnon, S., 2008. Movie Tourism - A New Form of Cultural Landscape?. Journal of Travel \& Tourism Marketing. 24 (2-3), pp. 154-162.

Karpovich, A. I., 2010. Theoretical Approaches to Film-Motivated Tourism. Tourism and Hospitality Planning \& Development, 7(11), pp.7-20.

Lovell, J. \& Bull, C., 2018. Authentic and Inauthentic Places in Tourism: From Heritage Sites to Theme Parks. Abingdon: Routledge.

MacCannell, D., 1973. Staged Authenticity: Arrangements of Social Space in Tourism Settings. American Journal of Sociology. 79 (3), pp. 357- 361.

Macionis, J. C.,2014. Understanding the Film-Induced Tourist. International Tourism and Media Conference 2004, 86-97.

Meng, Y. \& Tung, V., 2016. Travel Motivation of Domestic Film Tourists to the Hengdian World Studios: Serendipity, Traverse, and Mimicry. Journal of China Tourism Research. 12 (3-4), pp.434-450.

Moscardo, G. \& Pearce, P., 1985. Historic Theme Park: An Australian Experience in Authenticity. Annals of Tourism Research. 13(3), pp. 467-479.

Noy, C., 2007. The Poetics of Tourist Experience: An Autoethnography of a Family Trip to Eilat. Tourism and Cultural Change. 5(3), pp. 141-157.

Oviedo-García, M. A., Castellanos-Verdugo, M., Trujillo-García, A. and Mallya, T., 2014. Film-induced tourist motivations. The case of Seville (Spain). Current Issues in Tourism, 19 (7), 713-733.

Paasonen, S. (2015). Heavy skies and a cold Soviet feel: Helsinki as a Cold War cinematic body double. Journal of Scandinavian Cinema. 5(1). pp.5-18

Pearce, D. (1995). Tourism Today: A Geographical Analysis. Harlow: Longman.

Pons, P., 2003. Being-on-Holiday: Tourist Dwelling, Bodies and Place. Tourist Studies. 3(1), pp. 47-66.

Richards, G., 1996. Cultural Tourism in Europe. Wallingford: CAB International. 
Riley, R. W. \& Van Doren, C. S., 1992. Movies as Tourism Promotion: A 'Pull' Factor in a 'Push' Location. Tourism Management, 13(3), 267-274.

Riley, R. W., 1994. Movie Induced Tourism. In A. V. Seaton (et al) ed. Tourism: The State of the Arts. New Jersey: Wiley. pp. 453-458.

Rittichainuwat, B., Laws, E. \& Scott, N., 2018. Authenticity in Screen Tourism: Significance of Real World and Substituted Screen Locations. Journal of Hospitality \& Tourism Research. 42 (8), pp.1274-1294.

Roberts, L., 2016. On Location in Liverpool: Film-related tourism and the consumption of place. Philip Long \& Nigel D. Morpeth (eds) Tourism and the Creative Industries: Theories, Policies and Practice, pp.31-43.

Roesch, S., 2009. The Experiences of Film Location Tourists, Bristol: Channel View Publications.

Steiner, C., \& Reisinger, Y., 2006. Understanding Existential Authenticity. Annals of Tourism Research. 33(2), pp. 299-318.

Urry, J. \& Larsen, J., 2011. The Tourist Gaze 3.0. London: SAGE Publication Ltd.

Visit Liverpool., n.d. St George's Hall - Film Tour [Online] Available at: https://www.ticketquarter.co.uk/visitliverpool/Online/default.asp?BOparam::WSconten t::loadArticle::permalink=sgh-filmtour\&BOparam::WScontent::loadArticle::context_id= [Access on 15th March 2020]

Wang, N., 1999. Rethinking Authenticity in Tourism Experience. Annals of Tourism Research. (26), pp. 349-370.

Yen, C \& Croy, W. G., 2016. Film Tourism: Celebrity Involvement, Celebrity Worship And Destination Image. Current Issues in Tourism. 19 (10), pp. 1027-1044.

\section{Biography}

Xin Cui is a PhD candidate at the Department of Communication and Media, University of Liverpool. In her $\mathrm{PhD}$ research project, she is looking at the impacts of film-related tourism on the destination city's place image, identity and history through using a Chinese town Hengdian as the case. Her primary research interests are in film-related tourism studies and the impacts of media tourism.

Email: Xin.Cui@liverpool.ac.uk 